Anna Romanik

Uniwersytet w Białymstoku

Wydział Filologiczny

Instytut Filologii Wschodniosłowiańskiej

tel. +48857457450

e-mail: aniaromanik8@wp.pl

\title{
Specyfika językowa rosyjskiej nomenklatury z zakresu medycyny estetycznej i chirurgii plastycznej
}

Słowa kluczowe: ekwonimia językowa, internacjonalizm, język rosyjski, medycyna, nominacja, zapożyczenie

\section{Wprowadzenie}

Dbałość o urodę i związany z nią kult piękna, towarzyszący ludzkości od jej zarania, zdeterminowały narodzenie się działu medycyny, która w sposób mniej lub bardziej inwazyjny poprawia atrakcyjność fizyczną pacjenta. Już w starożytności odnotowano pierwszą udokumentowaną operację plastyczną nosa przeprowadzoną na zwłokach faraona Ramzesa II, co zgodnie z ówczesnymi wierzeniami miało mu zapewnić stosowną pozycję $\mathrm{w}$ życiu pozagrobowym [„Код молодости”, весна 2016, изд. 6, с. 25]. Medycyna plastyczna kształtowała się na przestrzeni tysiącleci, natomiast duży wpływ na jej intensywny rozwój miały różne konflikty zbrojne (wojny światowe w ubiegłym stuleciu), w trakcie których zastosowano wiele nowatorskich metod rekonstrukcyjnych ciała ludzkiego. Natomiast medycyna estetyczna funkcjonuje jako stosunkowo młoda dziedzina medycyny - formalnie została zarejestrowana we Francji w latach 70-tych XX wieku.

Niniejsze rozważania są próbą określenia specyfiki językowej rosyjskiego leksykonu medycyny estetycznej i plastycznej. W tym celu poddano analizie zjawisko zapożyczenia jako najbardziej produktywnego sposobu nomi- 
nacji językowej w danej branży. Badaniami objęto także aspekt proweniencji, struktury wyekscerpowanego materiału oraz innych zjawisk językowych charakterystycznych dla analizowanego słownictwa. Wybór obszaru badawczego nie był przypadkowy, ponieważ w Rosji w szczególności w ostatnich latach medycyna plastyczna i estetyczna jest niezwykle popularna i rozwija się dynamicznie. Materiał faktograficzny został wyekscerpowany przede wszystkim ze źródeł internetowych (ofert klinik medycyny estetycznej) ${ }^{1}$ oraz elektronicznej wersji czasopisma specjalistycznego „Код молодости”, publikowanego w latach 2015-2016. Ze względu na szeroką bazę leksykalną w zakresie medycyny estetycznej i chirurgii plastycznej materiał empiryczny ograniczono do jednostek wyrażonych imiennymi częściami mowy. Głównym obiektem analizy językowej są określenia estetycznych i kosmetycznych zabiegów medycznych oraz procedur chirurgicznych. Badaniami objęto również nazwy wybranych produktów kosmetycznych używanych w danej dziedzinie oraz inne nominacje, które reprezentują ciekawe przypadki onomazjologiczne, warte skomentowania.

Zgromadzone słownictwo stanowi interesujący i zróżnicowany pod wieloma względami zbiór jednostek leksykalnych. Analizowane nominacje pochodzą z różnych warstw czasowych. Spora ich część to nazwy o ustabilizowanej już w danej nomenklaturze medycznej pozycji, inne - najnowsze neologizmy, niekiedy mało zrozumiałe dla użytkowników języka. Niektóre zabiegi są znane i praktykowane od wielu dziesięcioleci, niemniej jednak w zawrotnym tempie pojawiają się nowe rewolucyjne metody lecznicze i profilaktyczne stosowane w omawianej branży, na przykład:

лигоментотомия - удлинение полового илена,

гименопластика - востановление девственной плевь, шлифовка - инновачионая методика безоперачионного лифтинга кожи,

липофилинг - революиионная методика пересадки жировой ткани.

\section{Nominacja językowa w zakresie medycyny estetycznej - zapożyczenia}

Nominacja językowa znajduje się w centrum zainteresowań wielu badaczy, co wcale nie dziwi, bowiem wszelkie modele nazewnicze mają to do siebie, że z biegiem czasu pod wpływem zarówno czynników językowych,

1 Szczegółowy opis źródłowy stron internetowych zamieszczono na końcu publikacji w spisie bibliograficznym. 
jak i pozajęzykowych stają się mniej lub bardziej produktywnymi albo też pojawiają się zupełnie nowe sposoby nazywania rzeczywistości. Fakty te wymagają stałego odnotowywania. W rosyjskiej lingwistyce powstało sporo wartościowych prac poświęconych teorii nominacji. Autorami tych publikacji są, między innymi, E. S. Kubriakowa [2010], B. A. Sieriebriennikow [1977], D. N. Szmielew [1982], A. A. Ufimcewa [2010], A. F. Żurawlew [1982] i inni. Niemniej współczesny język rosyjski doświadcza radykalnych zmian na różnych jego poziomach, w tym także w zakresie nominacji, stąd też bierze się konieczność kontynuowania badań onomazjologicznych.

Podejmując próbę zdefiniowania technik nominacyjnych używanych do kreowania słownictwa w wybranym obszarze językowym, warto zaakcentować fakt, że na badany materiał składają się przede wszystkim terminy medyczne, tworzące specyficzny zbiór jednostek leksykalnych. Stanisław Gajda [1990, 39] określając cechy dyferencjalne terminu wskazuje, między innymi, na ich jednoznaczność, stylową neutralność, systemowość oraz definicyjność. Przytoczony rejestr cech terminu determinuje dominację określonych sposobów nominacji w zakresie terminologii medycznej, które również tworzą charakterystyczny system nazewniczy, różniący się pod względem produktywności konkretnych modeli nazwotwórczych od systemu nominacyjnego ogólnego języka literackiego.

Istotnym czynnikiem wpływającym na nominację językową w przestrzeni medycznej są przesłanki pozajęzykowe. Należy pamiętać, że analizowany dział medycyny rozwija się niezwykle dynamicznie i nowe technologie oraz metody leczenia promowane sa przez kraje bardziej uprzemysłowione (Stany Zjednoczone, kraje Europy Zachodniej), co w sposób oczywisty wpływa na formowanie leksykonów medycznych. Poza tym medycyna od wieków dąży do ujednolicenia terminologii, którą się posługuje, w celu polepszenia komunikacji branżowej na całym świecie, a co za tym idzie bezbłędnego porozumiewania się nie tylko specjalistów, ale też zwykłych użytkowników wspólnoty dyskursu. L.F. Jelcowa [2009, 666] komentuje to w sposób następujący: „Медицинская терминология как средство формирования и сохранения знаний и прежде всего как средство обмена информацией, требует стандаризации, унификации и упорядочнения терминов, используемых специалистами".

Z przeglądu zgromadzonego materiału empirycznego wynika, że dominującym sposobem nominacji $\mathrm{w}$ danym obszarze leksykalnym jest zapożyczanie słownictwa z innych języków. Głównym donorem dystrybucji nowych nazw jest język angielski, z którego pożyczki są przejmowane bezpośrednio, albo też spełnia on rolę pośrednika w procesie importu leksykalnego z zasobu 
słownictwa innych języków, w tym przypadku przede wszystkim z języków klasycznych, tj. łacina i greka. Zresztą greko-latynizmy w każdej dziedzinie medycyny, nie tylko plastycznej i estetycznej, stanowią bazę derywacyjną w kształtowaniu leksykonów, to właśnie na nich opiera się terminologia medyczna. Autor monografii Латинский язык и основы медицинской терминологии, М. N. Czerniawski [2007, 36], w sposób szczegółowy opisuje rolę tych dwóch języków w kształtowaniu nomenklatury medycznej. Podkreśla on ich przewagę nad słownictwem rodzimym, przytaczając następujące argumenty:

Перед словами из живых национальных языков они имеют по крайней мере два преимущества: во-первых, легко включаются в терминологические системы, в которых в соответствии с многовековой традицией используются слова и словообразовательные элементы классических языков; во-вторых, их значения не претерпевают измененений под влиянием процессов, происходящих обычно в живых языках. Кроме того, словам и словообразовательным элементам греко-латинского происхождения можно придать специальные значения, которыми они не обладали в языке-источнике.

Z przeglądu zebranych egzemplifikacji wynika, że zapożyczenia adaptują się w języku-biorcy w sposób zróżnicowany. Niektóre przedostają się do języka rosyjskiego w postaci transplantów, tzn. w postaci niezmienionej, aczkolwiek dostosowują się do systemu morfologicznego i graficznego, np. anglicyzту бодиконтур, фейслифтинг, шугаринг, липофилинг, тредлифтинг, графтинг, пилинг, филлер, сzy też galicyzmy термаж, дренаж. Natomiast inne asymilują się w postaci kalki, co w dużym stopniu utrudnia już zdefiniowanie ich pochodzenia. Na przykład takie jednostki jak nересaдкa волос, пересадка жира, увеличение груди, należy również traktować jako zapożyczenia, mimo że z formalnego punktu widzenia te nazwy zabiegów w swojej strukturze zawierają elementy rodzime. Niemniej jednak są to kalki następujących wyrażeń przejęte z angielszczyzny: Hair Replacement, Fat Grafting, Breast Lift.

Warte odnotowania są również nominacje, które przedostały się do języka rosyjskiego w wyniku transferu leksykalnego w postaci wtrętu w zapisie łacińskim, na przykład: Aptos, Body Shape, Filament Lifting, GreenMask, MonaLisa Touch, Space Lifting, Thermage. Jak widać zapożyczenia przejęte $\mathrm{w}$ oryginale mogą funkcjonować jako samodzielne nazwy, bądź też jako jedna z podstaw złożenia, gdzie druga podstawa występuje w grafii cyrylickiej (Sтоотh-омоложение, Gold-лифтинг, Palomar-эnилячия). Kreolizowane jednostki są coraz częściej odnotowywane w pisemnym wariancie współczesnego języka rosyjskiego [Romanik 2016, 172], również w danym obszarze 
leksykalnym. Z jednej strony jest to zdeterminowane ogólnymi tendencjami latynizacji współczesnego języka rosyjskiego [Marinowa 2007, 325], a z drugiej strony wynika z faktu dynamicznego rozwoju medycyny estetycznej i pojawiania się w błyskawicznym tempie na Zachodzie nowych zjawisk i ich nazw, które przejmowane są przez języki zapożyczające w pierwotnej postaci, tzn. w grafice łacińskiej.

\section{Charakterystyka strukturalno-semantyczna}

Badane jednostki wykazują różnice na poziomie strukturalnym. Wśród nich znajdują się nominacje proste (имплантьл, лифтинг, пилинг, шугаринг) złożenia (ботулинотерапия, гипергидроз, липостимуляиия, маммопластика, мусс-пилинг, фейслифтинг, филлерь-нити) oraz nazwy reprezentowane przez zestawienia wielowyrazowe (золотое армирование, лазерная эпилячия, пластика ушньх раковин, передаска волос, уменьшение половых губ). Należy podkreślić, że wspomniane nominacje proste funkcjonują samodzielnie w ofertach klinik medycyny estetycznej, na portalach internetowych, czy też w tekstach artykułów zamieszczonych na łamach analizowanych periodyków, jednak ze względu na potrzebę precyzji w nazywaniu konkretnych zabiegów zdecydowanie częściej stanowią one element składowy bardziej rozbudowanych struktur, takich jak kompozyty czy zestawienia.

Dominującą pozycję w badanym zbiorze zajmują złożenia, które ze względów graficznych, czy też ze względu na stopień autonomii podstaw słowotwórczych danych jednostek, tworzą zróżnicowany zbiór nominacji. W zdecydowanej większości kompozyty są reprezentowane przez jednostki utworzone w oparciu o wspomniane już języki klasyczne, głównie łacinę i grekę. Tłumaczy się to faktem, że medycyna przecież, a tym samym język, jakim się posługuje, kształtowała się już w czasach antycznych. Niektóre elementy greckiej i łacińskiej proweniencji wykazują dużą aktywność derywacyjną, tworząc dość liczebne szeregi wspólnordzeniowe. Mowa tu o takich podstawach, jak: абдомен (лат. живот), лимфа (лат. влага, иистая вода), терапия (греч. служение ч-л., уход за кем-л.), пласти$\boldsymbol{\kappa a}$ (греч. искусство лепки, ваяние), скопия (др.-греч. всматриваться, взирать), блефаро (др.-греч. веко), маммо (лат. женская грудь), рино (др.-греч. нос), липо (др.-греч. жир), крио (др.-греч. холод).

Przytoczone klasycyzmy stają się często bazą gniazd słowotwórczych integrujących terminy zbieżne semantycznie. Na przykład leksem greckiego pochodzenia пластика stanowi podstawę sporej grupy struktur złożonych 
(абдоменопластика, аутопластика, блефаропластика, брахиопластика, вагинопластика, гименопластика, глютеопластика, маммопластика, ринопластика, отопластика, перинеопластика, платизмопластика, фаллопластика, хейлопластика). Również leksem терапия tworzy stale powiększającą się o nowe jednostki grupę terminów złożonусh (аутогемотерапия, ботулинотерапия, гидроасопотерапия, гидроколонотерапия, гирудотерапия, иглорефексотерапия, интралипотерапия, липотерапия, мезотерапия, озонотерапия, парафинотерапия, светотерапия, склеротерапия, SPRS-терапия). Anglicyzm лифтинг, który w badanej nomenklaturze funkcjonuje samodzielnie lub też jako jedna z podstaw kompozytów lub zestawien, także jest frekwencyjnie częstym elementem składowym zbioru wspólnordzeniowego (криолифтинг, миолифтинг, плазмолифтинг, радиолифтинг, сферолифтинг, термолифтинг, тредлифтинг, фейслифтинг, филаментлифтинг, АRT-лифтинг, SMAS-лифтинг).

Wprawdzie przytoczone przykłady są reprezentowane przez struktury złożone, niemniej jednak trudno uznać je wszystkie za derywaty sensu stricto, ponieważ można przypuszczać, że w zdecydowanej większości przedostały się do języka rosyjskiego w wyniku transferu leksykalnego głównie za pośrednictwem języków europejskich. Zresztą wiele przytoczonych kompozytów posiada status internacjonalizmów ${ }^{2}$, co oznacza, że w podobnej formie występują w innych językach narodowych (zob. dalej).

Wśród jednostek złożonych wyodrębnić można także struktury złożone współrzędnie. Są to głównie nazwy specjalistów działających w omawianej branży, czy też określenia produktów i sprzętu, rzadziej nazwy zabiegów.

Kolejny zbiór jednostek nominalnych tworzą struktury analityczne, wśród których można zidentyfikować różne modele formalne. W konstrukcji pierwszego wariantu w roli konstytutywnego elementu występuje rzeczownik, natomiast w roli członu określającego - przymiotnik. Przydawka przymiotna, znajdująca się w prepozycji względem elementu podstawowego, zawiera jednoznacznie zdefiniowaną motywację całego wyrażenia. Może ona definiować obszar ciała, w którego obrębie wykonywany jest zabieg (вагuнальное омоложение, груднье импланть), wskazywać metodę przeprowadzania zabiegu z uwzględnieniem użycia konkretnego oprzyrządowania

2 Ustalenie proweniencji terminów o statusie internacjonalizmów, derywowanych na bazie języków klasycznych, w wielu przypadkach może okazać się wręcz niemożliwe. Wynika to z faktu, że model słowotwórczy omawianych kompozytów w różnych krajach jest taki sam, więc nie mając pełnej wiedzy na temat kto pierwszy wymyślił dany zabieg i tym samym nadał nazwę konkretnemu desygnatowi, trudno jednoznacznie odtworzyć jego etymologię. 
(вакуумный массаж, инъекционная липотерапия, лазерная эпиляиия, лазерное омоложение, лазерная ииркумиизия, лазерная шлифовка, ультразвуковая абляиия), określać środki, produkty używane do przeprowadzenia danych procedur (аминокислотная терапия, нитевой лифтинг, сахарный скраб, тканевые экспандеры, плачентарная терапия, химический пилинг, газожидкостный пилинг), wskazywać cel zabiegu (редукиионная маммопластика) lub też określa charakter zabiegu (интимная пластика, контурная пластика, золотое армирование).

Równie popularnym modelem zestawień dwuwyrazowych są struktury składające się z podstawy wyrażonej rzeczownikiem oraz przydawki rzeczownej $\mathrm{w}$ formie dopełniacza, który przede wszystkim wskazuje na obiekt zabiegu, na przykład: дермотония лица, имплантачия груди, иссечение (крайней) плоти, коррекиия морщин, коррекиия фигурь, коррекция ягодии, липофилинг груди, моделирование рук, мезотерапия волос, обнажение клитора, передаска волос, подтяжка лба, подтяжка лица, плазмолифтинг головы, пластика живота, трансплантачия волос, увеличение груди, увеличение губ, удаление геморроя, уменьшение половых губ, устранение потливости. Jednostkowy przypadek stanowi dopełniaczowe zestawienie, gdzie przydawka określa subiekta, któremu przypisuje się autorstwo danego zabiegu - лифтинг Мендельсона (иначе Space Lifting - новая философия пластики, предложенная Браяном Мендельсоном, австралийским хирургом, доказывающая, что омолаживающие операции могут быть не только эффективнылми, но и малотравматичньлми) [„Код молодости”, 5 выпуск, зима 2015-2016, c. 13].

Użycie w nomenklaturze medycyny estetycznej binarnych konstrukcji składniowych ma swoje uzasadnienie, ponieważ takie właśnie wielowyrazowe nazwy posiadają właściwości detalizacji pojęcia, co w wielu przypadkach w konsekwencji ułatwia pacjentom zrozumienie sensu konkretnego zabiegu.

Ostatnią grupę tworzą struktury składniowe składające się minimum z trzech elementów, na przykład: контурная пластика лица, коррекция асимметрии груди, коррекиия кривизны ног, отбеливание интимных зон, удлинение полового илена, утолщение полового илена.

Jak widać z powyższej prezentacji struktur materiału empirycznego, dominujące miejsce zajmują konstrukcje złożone o podrzędnej relacji członów oraz nazwy wielowyrazowe. Natomiast na peryferiach danego zbioru znalazły się jednostki o współrzędnym złożeniu podstaw, np.: филлеры-нити, мусс-пилинг, психолог-трансплантолог, стоматолог-терапевт, косметолог-дерматолог, врач-офтальмолог. 


\section{Internacjonalizmy w nomenklaturze medycyny estetycznej i chirurgii plastycznej}

Warto zaakcentować fakt, że w badanym obszarze leksykalnym istotne miejsce przypada jednostkom, którym można przypisać status internacjonalizmów, o czym wspominano wcześniej. Zgodnie z definicją słownikową leksyka internacjonalna to „слова общего происхождения, существующие во многих языках с одним и тем же значением, но обычно оформляемые в соответсвии с фонетическими и морфологическими нормами данного языка" [Rozental, Telenkova, 2003, 148]. Dowodem istnienia leksemów o zasięgu międzynarodowym są zestawienia egzemplifikacji z różnych grup bądź podrodzin językowych, w których występuje konkretna jednostka. Więc na przykład funkcjonujące w języku rosyjskim terminy абдоминопластика, блефаропластика, дермабразия, липосакиия, маммопластика, ринопластика, w podobnej formie występują między innymi w językach:

- hiszpańskim (abdominoplastia, blefaroplastia, dermoabrasion, liposuccion, mamoplastia, rinoplastia),

- angielskim (abdominoplasty, blefaroplasty, dermoabrasion, liposuction, mammoplasty, rhinoplasty),

- francuskim (abdominoplastie, blepharoplastie, dermabracion, liposuccion, mamoplastie, rhinoplastie),

- polskim (abdominoplastyka, bleforoplastyka, dermobrazja, liposukcja, mammoplastyka, rinoplastyka).

Wszystkie powyżej przytoczone jednostki terminologiczne, pomimo różnic graficznych i morfologicznych (głównie fleksyjnych) wynikających z przynależności do innych systemów językowych, zachowują wspólne rdzenie i są określeniami dokładnie tego samego desygnatu. Cechy te predysponują dane jednostki do statusu internacjonalizmów.

Szczególna rola przypadająca leksemom o charakterze międzynarodowym, które funkcjonują w dyskursie medycznym, wynika z różnych przyczyn. Julia Mazurkiewicz-Sułkowska [2015, 169] zauważa, że w literaturze przedmiotu od wielu lat akcentuje się istotę jednoznaczności internacjonalizmów oraz fakt, że nie wywołują one żadnych konotacji. Ułatwia to komunikację $\mathrm{w}$ zasięgu globalnym, ponieważ wymiana treści medycznych przez użytkowników różnych języków jest wówczas zrozumiała i precyzyjna.

Z przeglądu zgromadzonego słownictwa rosyjskiego z zakresu medycyny estetycznej i chirurgii plastycznej wynika, że leksemy o statusie internacjonalizmów zazwyczaj mają swoje synonimiczne określenia, które niejednokrotnie są dosłownymi kalkami tych właśnie terminów. Współistnie- 
nie w danej nomenklaturze terminów całkowicie zbieżnych znaczeniowo jest w literaturze przedmiotu określane jako ekwonimia językowa [Lukszyn, Zmarzer, 2006, 38-39]. Taki właśnie dualizm nominacyjny można zaobserwować w przypadku wielu egzemplifikacji. Na przykład:

абдоминопластика - пластика живота,

блефаропластика - пластика век,

гименопластика - востановление девственности (девстенной плевbl),

гипергидроз - устранение потливости,

фейслифтинг - подтяжка лица,

ииркумиизия - обрезание крайней плоти,

Body Shape - контурная пластика тела.

Koegzystencja przytoczonych przykładów świadczy o ich pewnego rodzaju rywalizacji w języku. Przyglądając się ofertom klinik medycyny estetycznej mimo wszystko trudno wskazać, który z wariantów frekwencyjnie dominuje. Użycie jednej opcji lub drugiej wydaje się być subiektywnym wyborem autorów artykułów czy też twórców stron internetowych z ofertami zabiegów medycznych. Jednak Maryna Czwalińska [2015, 59] w oparciu o przeprowadzone badania słownikowe stwierdza, że medyczny język rosyjski częściej sięga po terminy o charakterze internacjonalnym, czyli głównie pożyczki.

Ekwonimia językowa, którą w dyskursie medycznym można uznać za zjawisko powszechne, wywołuje pewnego rodzaju kontrowersje wśród badaczy języka. Z jednej strony, paralele semantyczne prowadzą do synonimii językowej, co przeczy postulatom jednomianowości, wynikającym z podstawowej definicji terminu i tym samym prowadzi do pewnego rodzaju galimatiasu nominacyjnego w zakresie terminologii. Natomiast patrząc na problem ekwonimii z uwzględnieniem procesu ewolucji języka i zrozumienia nieuchronności tego faktu, nie należy oceniać jej negatywnie. Powyższe badania wykazują bowiem, że współistnienie różnych określeń tego samego pojęcia mimo wszystko ma raczej charakter harmonijny, zatem można mówić o ich kompatybilności.

\section{Podsumowanie}

Reasumując, warto podkreślić, że z lingwistycznego punktu widzenia badana nomenklatura z zakresu medycyny estetycznej i chirurgii plastycznej pod wieloma względami stanowi interesujący zbiór jednostek leksykalnych. Po pierwsze, uwzględniając aspekt onomazjologiczny badanego ob- 
szaru, okazało się, że najbardziej produktywnym sposobem nominacji jest zapożyczanie leksemów, w głównej mierze z języka angielskiego lub za jego pośrednictwem. Chociaż należy w tym miejscu zaznaczyć, że bezpośrednim dawcą transferu leksykalnego są języki klasyczne, takie jak łacina czy greka. Fakt ten nie dziwi, ponieważ zdecydowaną większość materiału empirycznego stanowią terminy medyczne, które zgodnie z wielowiekową tradycją nazewniczą derywowane są na bazie klasycznego zasobu leksykalnego. Po drugie, analizując strukturę zgromadzonego słownictwa, odnotowano dominację struktur złożonych (kompozytów i zestawień) jako formacji z szerokimi możliwościami detalizacji pojęć, a co za tym idzie - wyróżniającymi się dużym stopniem precyzji semantycznej. Badania wykazały także, że specyficzne dla danego słownictwa jest funkcjonowanie w nim z ekwonimów przejawiających dualizm językowy, a także internacjonalizmów, świadczących między innymi o permanentnej potrzebie ujednolicania języka medycznego oraz o skali globalizacji i popularności medycyny estetycznej i chirurgii plastycznej we współczesnym świecie.

\section{Literatura}

Gajda S., 1990, Wprowadzenie do teorii terminu, Opole.

Lukszyn J., Zmarzer W., 2006, Teoretyczne podstawy terminologii, Warszawa.

Mazurkiewicz-Sułkowska J., 2015, Internacjonalizmy jako źródto ekwonimii w stowiańskiej terminologii technicznej (na materiale polskim, rosyjskim i butgarskim), „Studia z Filologii Polskiej i Słowiańskiej”, 50, Warszawa, s. 166-180.

Czwalińska M., 2015, Analiza porównawcza terminologii medycznej w języku polskim i rosyjskim, „W dialogu języków i kultur IV”, red. nauk. K. Fordoński, 七. Karpiński, Warszawa, s. 57-64.

Romanik A., 2016, $W$ językowej komitywie. O angielskich wtrętach językowych w rosyjskich czasopismach specjalistycznych, (w:) W poszukiwaniu tożsamości językowej, t. 1, pod red. Ż. Sładkiewicz, K. Wądołowskiej-Lesner, Gdańsk, s. $171-179$.

Ельцова Л.Ф., 2009, K вопросу о коммуникативном потенциале производного термина (На примере клинической терминологии), (в:) Горизонты современной лингвистики: традиции и новаторство: сборник в честь Е. С. Кубряковой, Москва, с. 665-668.

Журавлев А.Ф., 1982, Технические возможности русского языка в области предметной номинации, (в:) Способы номиначии в современном русском языке, Шмелев Д. Н. (отв. ред.), Москва.

Кубрякова Е.С., 2010, Теория номиначии и словообразование, 2-е изд., Москва.

Розеталь Д.Э., Теленкова М. А., 2003, Справочник по русскому языку. Словарь лингвистических терминов, Москва. 
Серебренников Б.А., Уфимцева А. А. (глав. редакторы), 1977, Языковая номиначия. Общие вопросы, Москва.

Уфимцева А.А., 2010, Лексическая номиначия (первичная нейтральная), Москва.

Чернявский М. Н., 2007, Латинский язык и основы медииинкской терминологии, изд. 3, Москва.

Большой словарь иностранных слов, 2012, составитель: В.Ю. Никитина, Москва.

Новый словарь иностранных слов, 2006, глав. ред. В.В. Адамчик, Минск.

„Код молодости” http://ge.mediest.ru/uslugi/svezhij_nomer_zhurnala_kod_molodo sti/ (20.11.2016)

http://ems-clinic.ru/medicinskiy-mikronidling.html (20.11.2016)

http://www.l-a.ru/plastic_surgery/ (20.11.2016)

http://www.artclinic.ru/ (21.11.2016)

http://www.westmed.ru/services/ (21.11.2016)

https://medestetik.gidm.ru/igallery (21.11.2016)

\title{
THE LINGUISTIC SPECIFICATION OF RUSSIAN COSMETIC AND PLASTIC MEDICINE LEXICON
}

\author{
S U M M A R Y
}

The given article is about Russian medical vocabulary, which is used in esthetic and plastic medicine. The analyzed material (for instance: names of cosmetic and esthetic procedures, plastic surgeries) was selected from specialized magazines, such as "Код молодости" and web-sides with esthetical clinics offers.

The main purpose of the paper is to point out the most productive ways of nominations, to describe structure of searched lexicon. Also the author of the paper pays attention for an interesting linguistic phenomenon, such as, internationalization and lexical dualism (equonyms). The research has shown that the process of borrowing from European languages or transfer by English from classic languages (Latin or Greek) are the most popular ways of nomination. Besides, searching the structure of excerpted material, it was observed, that compound and analytic terms and are typical form used in that language area. 